Volume 37 || Issue 2 | December 2013

ISSN 1030-0112

\title{
Austiralasja!n Journal of
}

Spectal

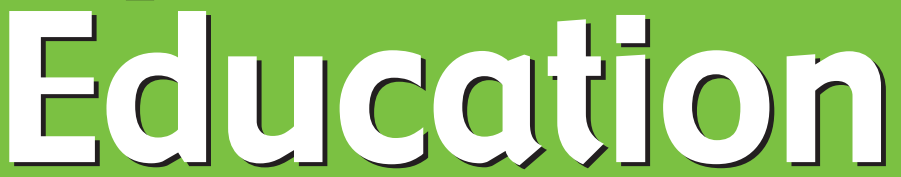

Journal of the Australian Association of Special Education

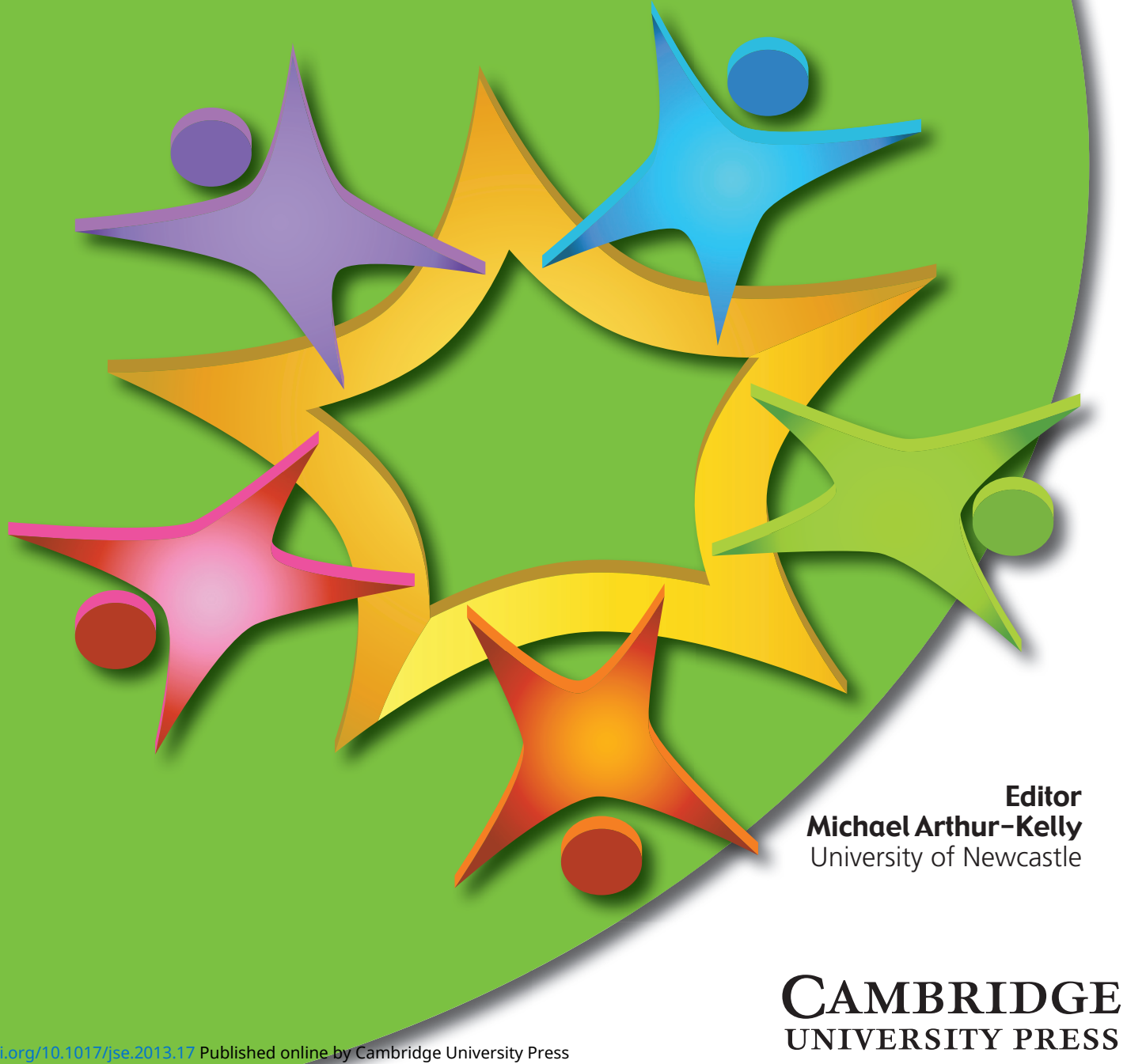




\section{Australasian Journal of Special Education}

The Australian Association of Special Education (AASE) aims to enhance access for students with special education needs to quality educational programs, promote professional standards of a high order and to support research that informs the delivery of special education in the Australian context.

To further these aims, The Australasian Journal of Special Education publishes articles for a readership professionally engaged or interested in the education of students with special needs or the education of those who will work with these students.
The Editor seeks articles in line with the theme of the journal — the delivery of educational programs to persons with special education needs: case studies, position papers, research reports, review papers and descriptions of research-based programs or classroom practices. Articles may be original qualitative or quantitative research papers, literature reviews, or conceptual articles relevant to any aspect of special education practice and policy.

\section{Editor Contact}

For any queries contact the Assistant Editor at Genevieve.Farrell@newcastle.edu.au

\section{Peer Review Policy}

All articles in this journal have undergone rigorous peer review, based on initial editor screening and anonymous refereeing by at least two expert referees.

Editor
Michael Arthur-Kelly
The University of Newcastle, Australia
Assistant Editor
Genevieve Farrell
The University of Newcastle, Australia
Book Review Editor
Sue O'Neill
University of New South Wales, Australia
Associate Editors
David Evans
The University of Sydney, Australia
Phil Foreman
The University of Newcastle, Australia
Chris Forlin
Hong Kong Institute of Education, Hong Kong
Keith Hyatt
Western Washington University, USA
Jennifer Stephenson
Macquarie University, Australia
Michael Townsend
Massey University at Auckland, New Zealand
Editorial Consultants
Alan Bain
Charles Sturt University, Australia
Susan Balandin
Victoria University of Wellington,
New Zealand
Robyn Bentley-Williams
Australian Catholic University, Australia
Richard Boon
The University of Sydney, Australia
Fiona Bryer
Griffith University, Australia
Jill Burgess
Australian Catholic University, Australia
Barry Carpenter
University of Oxford, UK
Suzanne Carrington
Aueensland University of Technology,
Markarie University, Australia
Macqualia

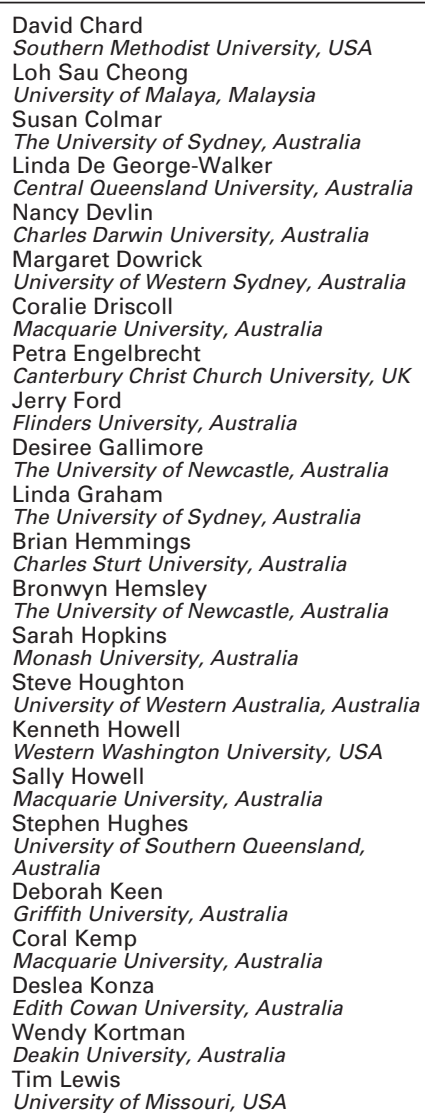

Kathleen Liberty

University of Canterbury, New Zealand Gordon Lyons

The University of Newcastle, Australia

Alison Madelaine

Macquarie University, Australia

Louise Mercer

Queensland University of Technology, Australia

Paul Pagliano

James Cook University, Australia

David Paterson

University of New England, Australia

Kim Fong Poon-McBrayer

Hong Kong Institute of Education, Hong Kong

Sue Ralph

University of Northampton, UK

Jacqueline Roberts

Griffith University, Australia

Tony Shaddock

University of Canberra, Australia

Umesh Sharma

Monash University, Australia

Jeff Sigafoos

Victoria University of Wellington,

New Zealand

Kenneth Kuen-Fung Sin

Hong Kong Institute of Education, Hong Kong Brenda Smith Myles

Ziggurat Group, USA

llektra Spandagou

The University of Sydney, Australia

Michael Steer

The University of Newcastle, Australia

Iva Strnadová

University of New South Wales, Australia

Dean Sutherland

University of Canterbury, New Zealand

Kathleen Tait

Hong Kong Baptist University, Hong Kong

Joanne Walker

University of Auckland, New Zealand

Kevin Wheldall

Macquarie University, Australia

\section{Australian Association of Special Education Incorporated}

\section{NATIONAL EXECUTIVE}

President: Lynne James (TAS)

Vice Presidents: Jennifer

Stephenson (NSW) and Virg

Summers (NT)

Secretary: Colleen Crawford

(TAS)

Treasurer: Peter Kirby (TAS)

Immediate Past President:

Gen Reynolds (SA)

Executive Officer: Tony Thomas

National Office

PO Box 211, Glen Iris,

VIC 3146

Membership Office

PO Box 2226, Bomaderry,

NSW 2541

\section{STATE CHAPTERS}

ACT: GPO Box 446, Canberra, ACT 2601

NSW: PO Box 2223, Bomaderry, NSW 2541

NT: PO Box 40528, Casuarina, NT 0811

QLD: PO Box 290, Aitkenvale, Townsville, QLD 4814

SA: c/- CEASA, Education Development Centre, Milner Street, Hindmarsh, SA 5007

TAS: c/- Colleen Crawford, Clarendon Vale Primary School, Mockridge Road, Clarendon Vale, TAS 7018

vIC: PO Box 1246, Healesville, VIC 3777

WA: PO Box 507, Leederville, WA 6903

\section{Subscription Rates 2013}

This journal is published biannually. The institutional rates (excluding VAT) are:

$\begin{array}{lcc} & \text { Print and online } & \text { Online only } \\ \text { Australia } & 258 \text { AUD } & 239 \text { AUD } \\ \text { N America } & 274 \text { USD } & 261 \text { USD } \\ \text { UK and ROW } & 177 \text { GBP } & 169 \text { GBP }\end{array}$

EU subscribers (outside the UK) who are not registered for VAT should add VAT at their country's rate. VAT registered subscribers should provide their VAT registration number. Prices include delivery by air when appropriate. Japanese prices for institutions are available from Kinokuniya Company Ltd, P.O. Box 55, Chitose, Tokyo 156, Japan. Orders and subscription enquiries should be addressed to: Cambridge University Press, The Edinburgh Building, Shaftesbury Road, Cambridge CB2 8RY, UK

Orders from N America should be addressed to: Cambridge University Press, Journals Fulfillment Department, 100 Brook Hill Drive, West Nyack, NY 10994-2133, USA

Journal subscription is covered by membership to the Australian Association of Special Education. For all enquiries, please contact the association:

PO Box 2226, Bomaderry, NSW 2541 Australia

Australasian Journal of Special Education and all other Cambridge Journals can be found at http://journals.cambridge.org/ 


\section{Austiralasian Jounal of \\ Special Education}

\section{Volume 37 | Issue 2 | December 2013}

\section{Contents}

\section{Articles}

Teacher Assistant Supports in Inclusive Schools:

Research, Practices and Alternatives

Michael F. Giangreco

Using Online Video-Recorded Interviews to

Connect the Theory and Practice of Inclusive

Education in a Course for Student Teachers

Christopher Rayner and Jeanne Maree Allen

One Year on: First-Year Primary Teachers'

Perceptions of Preparedness to Manage

Misbehaviour and Their Confidence in the

Strategies They Use

Sue O'Neill and Jennifer Stephenson

Copyright in all articles rests with authors. A limited set of permanent copyright permission licences has been granted by authors to the publisher to allow publication in this journal. Rights in the reproduction and distribution of the published articles as visual facsimiles of this published edition by either mechanical or digital means is controlled by the publisher and any distributions by CAL for copying of an author's work therefore are due to the publisher and AASE. All other rights in the words contained in this edition are controlled by the authors. Authors are therefore free to adapt and/or republish the words making up their own articles either online or in print.

Published by Cambridge University Press on behalf of Australian Academic Press Pty Ltd. and the Australian Association of Special Education Inc.

Cambridge University Press,

University Printing House

Shaftesbury Road

Cambridge CB2 8BS

United Kingdom

journals.cambridge.org

The Dissection of Paraprofessional Support in Inclusive Education: 'You're in Mainstream With a Chaperone'

Ben Whitburn

Tic Disorders and Learning Disability: Clinical Characteristics, Cognitive Performance and Comorbidity

Valsamma Eapen, Rudi Črnčec, Sarah McPherson and Corina Snedden

\section{Book Review}

Teaching in Inclusive School Environments 